\title{
Nitrogen digestion in sheep given poor-quality indigenous hill herbages
}

\author{
BY J. C. MACRAE*, J. A. MILNE, S. WILSON AND \\ ANGELA M. SPENCE
}

\author{
Hill Farming Research Organisation, Bush Estate, Penicuik, Midlothian, EH26 oPY \\ (Received 23 January 1979 - Accepted 22 May 1979)
}

\begin{abstract}
1. In two experiments, the sites of digestion of non-ammonia nitrogen (NAN) and the amounts of urea $N$ recycled to the rumen were measured in mature wether sheep given diets of indigenous hill herbage (AgrostisFestuca and heather).

2. Duodenal and ileal flow values were obtained using ${ }^{103} \mathrm{Ru}$-phenanthroline and ${ }^{51} \mathrm{Cr}$-EDTA markers in animals prepared with simple ( $\mathrm{T}$-shaped) cannulas. Amounts of urea $\mathrm{N}$ recycled to the rumen were estimated from measurements of the transfer of plasma urea carbon into rumen bicarbonate and the production rate of rumen bicarbonate using ${ }^{14} \mathrm{C}$-labelled urea and bicarbonate respectively.

3. The flows of NAN at the duodenum and ileum were linearly related to the intake of herbage $\left(P<0^{\circ} 001\right)$. There was a net gain of non-ammonia $\mathrm{N}$ anterior to the duodenum on both diets (at an intake of $460 \mathrm{~g}$ organic matter (OM)/d, $3.7 \mathrm{~g}$ NAN/d on Agrostis-Festuca and $3.3 \mathrm{~g}$ NAN/d on heather).

4. Net digestibility of NAN entering the small intestine was within a normal range on the AgrostisFestuca $(0.58$ at $460 \mathrm{~g} \mathrm{OM}$ intake) diet but low on the heather diet $(0.43$ at $460 \mathrm{~g} \mathrm{OM}$ intake).

5. It was calculated that at $460 \mathrm{~g} \mathrm{OM}$ intake only 0.9 and $\mathrm{I} \cdot 1 \mathrm{~g} / \mathrm{d}$ respectively of the duodenal NAN on the Agrostis-Festuca and heather diets could have been derived from urea-N recycled to the rumen. Thus $2 \cdot 8 \mathrm{~g}$ and $2 \cdot 2 \mathrm{~g} / \mathrm{d}$ had to be accounted for as non-urea endogenous NAN.
\end{abstract}

Two of the principal plant species ingested by hill sheep in the UK are Agrostis-Festuca and heather. Recent studies have shown the poor nutritive value of these forages in winter (Milne, 1974; Armstrong \& Eadie, 1977), with digestibilities of organic matter (OM) ranging from 0.45 to 0.55 and intakes of digestible energy that do not provide a maintenance diet. Indeed, ewes grazing hills with a mixed vegetation of indigenous grass and heather have been shown to lose $20 \%$ of their maternal tissues between November and April (Russel et al. 1968). In addition it has been shown that the apparent nitrogen digestibility of heather is much lower than its OM digestibility (Milne, 1974).

It has always been assumed that $\mathrm{N}$ digestion in the ruminant is at its most efficient when low-N diets are being consumed. Thus when poor-quality dried roughages are given there is a net gain of non-ammonia $\mathrm{N}$ (NAN) anterior to the small intestine (Clarke et al. 1966; Hogan \& Weston, 1967; Weston \& Hogan, 1968; Egan, 1974), which has been assumed to be derived mainly from the conversion of recycled urea $\mathrm{N}$ into microbial protein. However, little information is available on the quantitative aspects of this process.

The present study provides information on the sites of digestion of Agrostis-Festuca and heather diets and also indicates the contribution of recycled urea $\mathrm{N}$ to the apparent synthesis of NAN anterior to the small intestine of sheep given these diets. Part of the study has already been reported briefly (MacRae et al. 1977).

\section{EXPERIMENTAL}

Two separate experiments were carried out. Expt I was designed to measure the amounts of NAN entering and leaving the small intestine and excreted in faeces and urine of sheep given various amounts of Agrostis-Festuca (Expt I $a$ ) and heather (Expt I $b$ ). Expt 2 was designed to measure the amounts of urea degraded in the rumen on each of these diets, i.e.

* Present address: The Rowett Research Institute, Bucksburn, Aberdeen, AB2 9SB. 
Table I. Expts I and 2. Chemical composition ( $\mathrm{g} / \mathrm{kg}$ dry matter) and digestibility coefficient of organic matter $(O M)$ of herbages given

$\begin{array}{lcccccccc} & \begin{array}{c}\text { Expt } \\ \text { no. }\end{array} & \begin{array}{c}\text { Dry } \\ \text { (g/ter } / \mathrm{kg})\end{array} & \text { Ash } & \text { Nitrogen } & \begin{array}{c}\text { Neutral- } \\ \text { fetergent }\end{array} & \begin{array}{c}\text { Acid- } \\ \text { detergent } \\ \text { fibre }\end{array} & \begin{array}{c}\text { Acid- } \\ \text { detergent } \\ \text { lignin }\end{array} & \begin{array}{c}\text { Digestibility } \\ \text { of OM }\end{array} \\ \text { Agrostis-Festuca } & \text { I } a, 2 & 30.4 & 88 & 14.3 & 576.1 & 329.3 & 38.9 & 0.545 \pm 0.0071 \\ \text { Heather } & I b & 44.0 & 31 & 10.9 & 432.1 & 325.0 & 187.9 & 0.471 \pm 0.0073 \\ & 2 & 44.3 & 35 & 10.3 & 443.3 & 363.0 & 196.1 & 0.458 \pm 0.0046\end{array}$

by multiplying the proportion of rumen carbon dioxide which was derived from plasma urea by the production rate of rumen bicarbonate in sheep given the same herbage.

\section{Animals}

Mature Scottish Blackface wethers, $2-4$ years old and weighing $45-60 \mathrm{~kg}$ at the start of each experiment, were used throughout. In Expt I two groups of animals were prepared. Those used for collection of intestinal digesta (sites of digestion sheep; six sheep in Expt I $a$ and five sheep in Expt $I b$ ) were each prepared with a rumen cannula (Kay \& McKenzie, 1968) plus simple (T-shaped) cannulas in the proximal duodenum ( $50 \mathrm{~mm}$ beyond the pylorus) and terminal ileum (400-500 $\mathrm{mm}$ from the ileo-caecal valve) (Hecker, 1974). A further group used for digestibility and balance studies (balance sheep; seven sheep in Expt $\mathrm{I} a$ and five sheep in Expt $\mathrm{l} b$ ) were each prepared with a rumen cannula only.

The nine animals used in Expt 2 were each prepared with a rumen cannula plus two caecal cannulas (MacRae et al. 1973). Jugular catheters (into one vein for single injection experiments and into both veins for continuous infusion experiments) were inserted at least $24 \mathrm{~h}$ before each measurement period.

In both experiments the sheep were housed in metabolism crates under continuous artificial light (daylight was not excluded). They had free access to water at all times and received their rations from continuous-belt feeders. The sheep were in good body condition (condition score $2 \cdot 5-3$; Russel et al. 1969) before introducing them to the experimental diets. Depending on the level of intake to which they were allocated, the sheep lost $75^{-150} \mathrm{~g}$ live weight/d over the experimental periods.

\section{Herbage}

The Agrostis-Festuca herbage for both Expts I and 2 was harvested in October 1974 with a flail harvester from a site at House o' Muir Research Station, Midlothian, Scotland, and stored at $-20^{\circ}$. The frozen herbage was chopped before preparation of the rations.

Current season's shoots of heather were harvested with a modified small flail harvester in early November 1972 for Expt I and in September 1975 for Expt 2 from a site at Glensaugh Research Station, Kincardineshire, Scotland, and stored at $-20^{\circ}$ until offered to the animals.

Both frozen herbages were placed on the continuous-belt feeders at $12 \mathrm{~h}$ intervals. The chemical compositions of the herbages are given in Table $\mathrm{I}$.

\section{Radio-isotopes}

Preparation. ${ }^{103} \mathrm{RuCl}_{3},{ }^{51} \mathrm{Cr}$-EDTA, $\left[{ }^{14} \mathrm{C}\right]$ urea and $\mathrm{NaH}^{14} \mathrm{CO}_{3}$ were obtained from the Radiochemical Centre, Amersham. The ${ }^{103} \mathrm{RuCl}_{3}$ was converted into ${ }^{103} \mathrm{Ru}$-phenanthroline $\left({ }^{103} \mathrm{Ru}-\mathrm{P}\right)$ (Tan et al. $\left.\mathrm{I} 97 \mathrm{I}\right)$ and ${ }^{51} \mathrm{Cr}$-EDTA was diluted with carrier Cr-EDTA (Binnerts 
et al. 1968). The $\left.{ }^{14} \mathrm{C}\right]$ urea and $\mathrm{NaH}^{14} \mathrm{CO}_{3}$ used in Expt 2 were diluted with carrier urea $\left(3 \mathrm{mmol} / \mathrm{mCi}\right.$ ) and $\mathrm{Na}_{2} \mathrm{CO}_{3}(\mathrm{I} \mathrm{mmol} / \mathrm{mCi}$ ) respectively.

\section{Experimental procedures}

Expt $\mathrm{I}$. Partition of digestion. Both sites of digestion and balance groups of animals were randomly allocated to daily intakes of herbage ranging from 200 to $650 \mathrm{~g} \mathrm{OM}$ of AgrostisFestuca and from 275 to $5 \mathrm{IO} \mathrm{g} \mathrm{OM}$ of heather at least 3 weeks before the start of collection periods. The sites of digestion sheep each received a continuous infusion of ${ }^{103} \mathrm{Ru}-\mathrm{P}$ (approximately $25 \mu \mathrm{Ci} / \mathrm{d})$ and ${ }^{51} \mathrm{Cr}$-EDTA $(75 \mu \mathrm{Ci} / \mathrm{d})$, contained in approximately $30 \mathrm{ml}$ distilled water, into the rumen for $10 \mathrm{~d}$ before and throughout the collection period. Two separate $24 \mathrm{~h}$ duodenal plus two separate $24 \mathrm{~h}$ ileal spot-sampling procedures were carried out from each sheep. During collections $75^{-1} 00$ g digesta were obtained at 4 -hourly intervals. Later a composite $24 \mathrm{~h}$ sample was prepared for each sheep by accumulating $50 \mathrm{~g}$ of each sample. Samples were stored at $-20^{\circ}$ to await analysis. Following the 3 -week period of adjustment to the diet a standard ro d faeces and urine collection was made from the balance sheep.

Expt 2. Urea recycling. This experiment was carried out in two phases involving ( 1 ) intravenous (i/v) administration of $\left[{ }^{14} \mathrm{C}\right]$ urea and (2) intraruminal $(\mathrm{i} / \mathrm{r})$ administration of $\mathrm{NaH}^{14} \mathrm{CO}_{3}$. At least six days elapsed between the two phases to ensure that radioactivity had returned to background levels. Five sheep were given Agrostis-Festuca and allocated randomly to intakes ranging from 300 to $500 \mathrm{~g} \mathrm{OM} / \mathrm{d}$. Four of the five sheep received single injections of $\left[{ }^{14} \mathrm{C}\right]$ urea $\left(50 \mu \mathrm{Ci}\right.$ in $10 \mathrm{ml}$ sterile saline $\left(9 \mathrm{~g}\right.$ sodium chloride/l); the $5^{\text {th }}$ sheep received a continuous infusion $(0.07 \mu \mathrm{Ci}$ in $0.2 \mathrm{ml}$ saline/min). All five sheep received continuous infusions of $\mathrm{NaH}^{14} \mathrm{CO}_{3}(\mathrm{i} / \mathrm{r})(0.05 \mu \mathrm{Ci}$ in $0.3 \mathrm{ml} 0.02 \mathrm{M}$-sodium hydroxide/min) together with Cr-EDTA as a liquid-phase marker.

Four sheep were given heather and allocated randomly to intakes ranging from 240 to $740 \mathrm{~g} \mathrm{OM} / \mathrm{d}$. The four sheep received continuous infusions of $\left[{ }^{14} \mathrm{C}\right] \mathrm{urea}$ and three of them received $\mathrm{NaH}^{14} \mathrm{CO}_{3}(\mathrm{i} / \mathrm{r})$ infusions. Two of the four sheep receiving the continuous infusion of $\left[{ }^{14} \mathrm{C}\right]$ urea refused $300 \mathrm{~g} \mathrm{OM} / \mathrm{d}$ on the day of infusion and one sheep was withdrawn from the experiment before the $\mathrm{NaH}^{14} \mathrm{CO}_{3}$ infusion.

Following the $\mathrm{i} / \mathrm{v}$ single injections in Expt 2 jugular blood samples $(10 \mathrm{ml})$ were withdrawn through the catheters at 30,60, I20, 180, 280, 370, 460,600, 800, I 300 and $1700 \mathrm{~min}$ for plasma urea specific activity (SA) assays, and rumen fluid samples ( $15 \mathrm{ml}$ ) were collected at $15,30,40,50,75,100,130,170,210,280,370,460,600,800,1300,1700,22002900$ and $3100 \mathrm{~min}$ for rumen bicarbonate SA assays. The continuous infusions of $\left[{ }^{14} \mathrm{C}\right]$ urea $(\mathrm{i} / \mathrm{v})$ and $\left[{ }^{14} \mathrm{C}\right]$ bicarbonate $(\mathrm{i} / \mathrm{r})$ were maintained for at least $\mathrm{I} 6 \mathrm{~h}$. During the last $6 \mathrm{~h}$ of each infusion six or seven plateau samples were taken from the primary (receiving infusate) and secondary metabolite pools for SA assays of plasma urea and rumen bicarbonate.

\section{Laboratory procedures}

Analyses of representative samples of food and faeces from the balance sheep in Expt I were carried out on freeze-dried samples ground to pass a I $\mathrm{mm}$ sieve. Urine was collected into $50 \mathrm{ml} 3 \mathrm{M}$-hydrochloric acid and stored at $-20^{\circ}$ before analysis.

Analyses of the composite $24 \mathrm{~h}$ duodenal and ileal digesta samples were carried out on the whole freeze-dried digesta and also on the supernatant fraction obtained after centrifugation ( $2000 \mathrm{~g}$ for $20 \mathrm{~min}$ ). The supernatant fraction was taken to be the liquid phase of digesta and the $24 \mathrm{~h}$ flow-rates were calculated relative to ${ }^{51} \mathrm{Cr}$-EDTA concentrations. The particulate phase was taken as whole digesta-supernatant and flow-rates were expressed on a $24 \mathrm{~h}$ basis using the ${ }^{103} \mathrm{Ru}-\mathrm{P}$ values. 
Blood plasma was prepared by centrifuging whole blood in heparinized tubes at $3000 \mathrm{~g}$ for $20 \mathrm{~min}$.

Concentrations of total $\mathrm{N}$ in all samples were determined by a micro-Kjeldahl method. Ammonia $\mathrm{N}$ in rumen, duodenal and ileal digesta were determined by the Conway (1957) micro-diffusion method and urea $\mathrm{N}$ in plasma and urine by the autoanalyser method of Marsh et al. (1965).

Radioactivity assays of the ${ }^{103} \mathrm{Ru}-\mathrm{P}-{ }^{51} \mathrm{Cr}-\mathrm{EDTA}$ rumen infusate (approximately $0.1 \mathrm{~g}$, accurately weighed and then diluted to $10 \mathrm{ml}$ ) and of duodenal and ileal whole digesta (approximately to $\mathrm{ml}$ portions of the composite $24 \mathrm{~h}$ samples) were determined using a liquid-scintillation counter (NE 83 2 counter; Nuclear Enterprises, Sighthill, Edinburgh). After counting, the digesta was dried $\left(100^{\circ}\right.$ for $24 \mathrm{~h}$ ) to determine the dry matter concentration of the whole digesta counted.

Radioactivity assays of $\left[{ }^{14} \mathrm{C}\right]$ urea were carried out on accurately weighed amounts of infusate ( $0 . \mathrm{I} \mathrm{g})$ and deproteinized plasma (0.5-I.0 g) (Coccimano \& Leng, I967) in IO $\mathrm{ml}$ NE260 scintillator (Nuclear Enterprises, Sighthill, Edinburgh). Scintillation counting of $\left[{ }^{14} \mathrm{C}\right]$ bicarbonate infusates and rumen fluid samples was carried out in NE260 by the method described by MacRae \& Wilson (1978). The bicarbonate in rumen fluid was converted to barium carbonate (Leng \& Leonard, 1965) which was then dissolved in I $\mathrm{ml}$ EDTA-tetra sodium salt before addition of the scintillator (Io $\mathrm{ml}$ ) (MacRae \& Wilson, 1978). Counting efficiencies were determined by the channels ratio method, using $\mathrm{n}-\left[\mathrm{I}-{ }^{14} \mathrm{C}\right]$ hexadecane as a reference standard.

\section{Mathematical procedures}

In Expt I the $24 \mathrm{~h}$ flow of digesta constituents $(x)$ entering and leaving the small intestine was calculated from the equation:

$$
\left[\begin{array}{c}
\text { concentration of } \\
x(/ \mathrm{g} \text { whole digesta })
\end{array}-\begin{array}{c}
(\mathrm{L} \times \text { concentration of } \\
x(/ \mathrm{g} \text { supernatant })
\end{array}\right] \frac{{ }^{103} \mathrm{Ru} \text { counts } / \mathrm{min} \text { per } \mathrm{d} \text { infused }}{{ }^{103} \mathrm{Ru} \text { counts } / \mathrm{min} \text { per } \mathrm{g} \text { whole digesta }}
$$

$$
+(\mathrm{L} \times \text { concentration of } x(/ \mathrm{g} \text { supernatant })) \times \frac{{ }^{51} \mathrm{Cr} \text { counts } / \mathrm{min} \text { per } \mathrm{d} \text { infused }}{{ }^{51} \mathrm{Cr} \text { counts } / \mathrm{min} \text { per } \mathrm{g} \text { whole digesta }}
$$

where $\mathrm{L}=\mathrm{I}-\mathrm{DM}$ concentration of whole digesta.

In Expt $2 \mathrm{SA} v$. time for plasma $\left[{ }^{14} \mathrm{C}\right] \mathrm{urea}$ after single $(\mathrm{i} / \mathrm{v})$ injection was fitted by a firstorder exponential ( $A e^{-m t}$; where $t$ is the period after injection); the appearance of activity in rumen bicarbonate needed two or three exponents for best fit. An example of the SA $v$. time relationships for plasma $\left[{ }^{14} \mathrm{C}\right]$ urea and rumen $\mathrm{NaH}^{14} \mathrm{CO}_{3}$ are given in Fig. I. The ratio, area under the bicarbonate-C curve: area under urea C SA curve, gives an estimate of the proportion of bicarbonate- $C$ which is derived from urea- $C$ (see Nolan \& Leng, 1974).

$\mathrm{SA} v$. time for $\left.{ }^{\left[{ }^{14}\right.} \mathrm{C}\right]$ urea $(\mathrm{i} / \mathrm{v})$ and $\mathrm{NaH}^{14} \mathrm{CO}_{3}(\mathrm{i} / \mathrm{r})$ during the continuous infusion experiment was used to calculate the irreversible loss rates of urea $C$ and bicarbonate $C$ from the relationship; infusion rate of isotope:plateau SA. The percentage of rumen bicarbonate derived from plasma urea was calculated from the relationship, rumen bicarbonate plateau SA: plasma urea plateau SA (see Nolan \& Leng, I974).

The standard errors associated with the values obtained from regression equations were calculated by the method given by Steel \& Torrie (1960). 


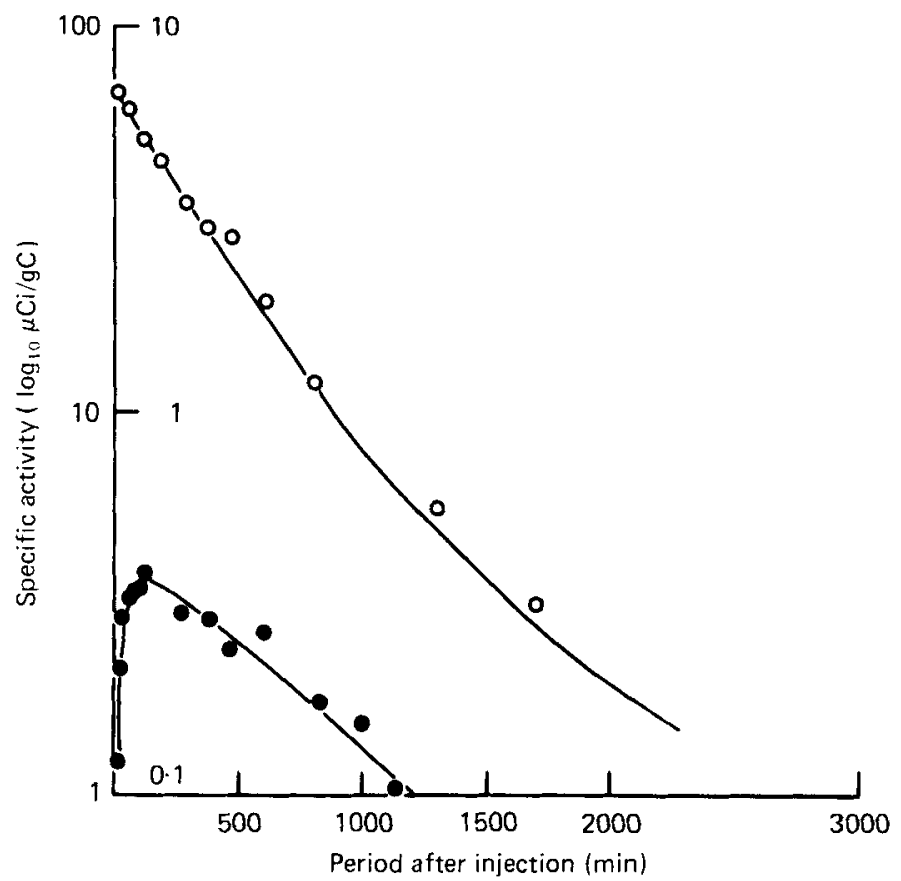

Fig. I. Specific activity $v$. time for plasma urea $C(O)$ and rumen bicarbonate $C(\bullet)$ following an intravenous injection of $54.7 \mu \mathrm{Ci}{ }^{14} \mathrm{C}$-urea into a sheep consuming Agrostis-Festuca $(307 \mathrm{~g} \mathrm{OM} / \mathrm{d})$. The equations were, for plasma $\left[{ }^{14} \mathrm{C}\right]$ urea, $A_{t}=687 \mathrm{I} 5 \mathrm{e}^{-0.0232 t}+\mathrm{I}$ I 93 and, for rumen $\mathrm{NaH}^{14} \mathrm{CO}_{3}$, $A_{t}=\left(470 \mathrm{e}^{0.00102 t}-4 \mathrm{I} \cdot 8\right)-\left(584 \mathrm{e}^{-0.0545 t}+36 \mathrm{I} \cdot 5\right)$. Where $t$ is period after injection (min).

\section{RESULTS}

\section{Expt I. Partition of $N$ digestion}

The relationship between $\mathrm{N}$ intake and the amounts of NAN entering and leaving the small intestine obtained from the sites of digestion sheep and the amounts of $\mathrm{N}$ excreted in faeces obtained from the balance sheep are presented in Fig. 2. The values were fitted by the linear regressions given in Fig. 2. The mean apparent $\mathbf{N}$ digestibility coefficient of the Agrostis-Festuca $(0.456 \pm 0.0590)$ was considerably higher than that of the heather $(0 \cdot 31 \mathrm{I} \pm 0.0180)$.

Values from the regressions given in Fig. 2 have been used to calculate NAN flows at the duodenum and ileum at an intake of $460 \mathrm{~g} \mathrm{OM} / \mathrm{d}$ for each herbage. This feeding level was the mean intake on the Agrostis-Festuca diet. At this intake $167( \pm 8 \cdot 4) \mathrm{g}$ and $\mathrm{I} 28( \pm 6 \cdot 3) \mathrm{g}$ $\mathrm{OM} / \mathrm{d}$ disappeared anterior to the duodenum with the Agrostis-Festuca and heather diets respectively. As a proportion of the total $O M$ ingested 0.33 and 0.40 disappeared anterior to the duodenum.

On both the Agrostis-Festuca and heather diets there was considerable net gain of NAN anterior to the duodenum. The $\mathrm{N}$ values given in Table 2 show that the sheep consumed $6.5 \mathrm{~g}$ and $5.0 \mathrm{~g} \mathrm{~N} / \mathrm{d}$ respectively at $460 \mathrm{~g} \mathrm{OM} / \mathrm{d}$ but that their duodenal flows of NAN were $10.2( \pm 0.74)$ and $8.3( \pm 0.23) \mathrm{g} / \mathrm{d}$. Thus there were net additions of 3.7 and $3.3 \mathrm{~g} \mathrm{NAN/d}$ anterior to the duodenum.

The ileal flows of NAN were $4.3( \pm 0.36)$ and $4.7( \pm 0.13) \mathrm{g} / \mathrm{d}$ for the Agrostis-Festuca and heather diets respectively. Thus the disappearance of NAN from the small intestine was considerably higher in the sheep given Agrostis-Festuca, compared to those given heather. From the regression equation of net digestibility of NAN in the small intestine and 


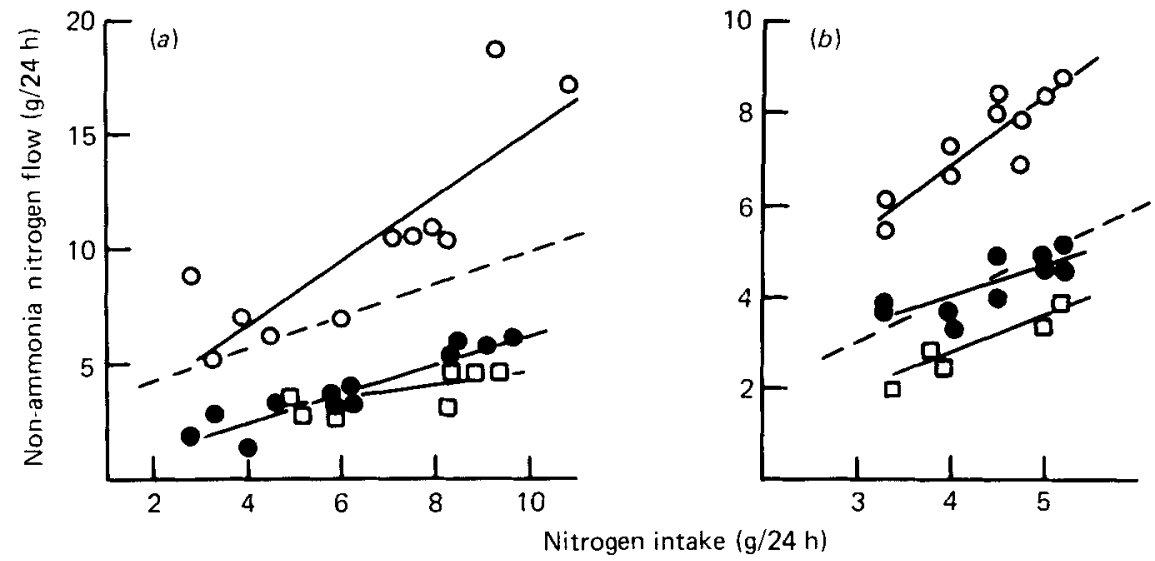

Fig. 2. Flows of non-ammonia nitrogen (NAN) through the proximal duodenum $(O)$ and terminal ileum ( $O$ ) and $\mathrm{N}$ in the faeces ( $\square$ ) of sheep given (a) Agrostis-Festuca and (b) heather at various $\mathrm{N}$ intakes (- - - ). Points represent one $24 \mathrm{~h}$ observation. Regression equations, with standard errors of the regression coefficients, were for Agrostis-Festuca:

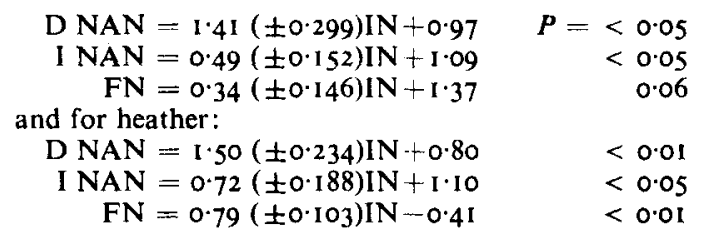

Where D NAN denotes duodenal NAN, I NAN denotes ileal NAN, FN denotes faecal N and IN denotes intakes of $\mathbf{N}$.

Table 2. Calculated amounts $(\mathrm{g} / \mathrm{d})$ of non-ammonia nitrogen $(N A N)$ entering and leaving the small intestine, and urea $N$ recycled into the rumen of a sheep given $460 \mathrm{~g} O M$ of AgrostisFestuca or heather/d

$N$ intake $(g / d)$

NAN* entering small intestine $(\mathrm{g} / \mathrm{d})$

$\mathrm{NAN}^{*}$ leaving small intestine $(\mathrm{g} / \mathrm{d})$

Net digestibility of NAN in small intestine

Over-all apparent $\mathrm{N}$ digestibility coefficients

Addition of NAN anterior to duodenum (g/d)

Plasma urea $\mathrm{N} \dagger$ entering rumen $(\mathrm{g} / \mathrm{d})$

Addition of non-urea endogenous NAN anterior to duodenum $(\mathrm{g} / \mathrm{d})$
Agrostis-Festuca Heather

$\begin{array}{cl}6.5 & 5 \cdot 0 \\ 10.2 & 8 \cdot 3 \\ 4.3 & 4 \cdot 7 \\ 0.58 & 0.43 \\ 0.46 & 0.29 \\ 3.7 & 3 \cdot 3 \\ 0.9 & 1 \cdot I \\ & \\ 2.8 & 2.2\end{array}$

* Values calculated from Fig. 2.

$\dagger$ Values calculated from Fig. 4 and the percentage of rumen bicarbonate derived from plasma urea $C$ (for details, see p. 532).

$\mathrm{N}$ intake, it was estimated that at an intake of $460 \mathrm{~g} \mathrm{OM} / \mathrm{d}$ the net digestibility of NAN in the small intestine was $0.58( \pm 0.045)$ for the Agrostis-Festuca diet and $0.43( \pm 0.026)$ with heather. Apparent absorptions of NAN from the small intestine $(5.9 \mathrm{~g} / \mathrm{d}$ for AgrostisFestuca and $3.6 \mathrm{~g} / \mathrm{d}$ for heather) were high relative to the apparently digestible $\mathrm{N}$ intakes ( 3.3 and $1.5 \mathrm{~g} \mathrm{~N}$ respectively).

The relationships between urea $\mathrm{N}$ excretion rates and $\mathrm{OM}$ intake for both diets are given in Fig. 3. There was a decline in excretion rate as intake was raised from 300 to $400 \mathrm{~g} \mathrm{OM} / \mathrm{d}$. On the grass diet there was a subsequent increase as intake rose above $450-500 \mathrm{~g} \mathrm{OM} / \mathrm{d}$. 


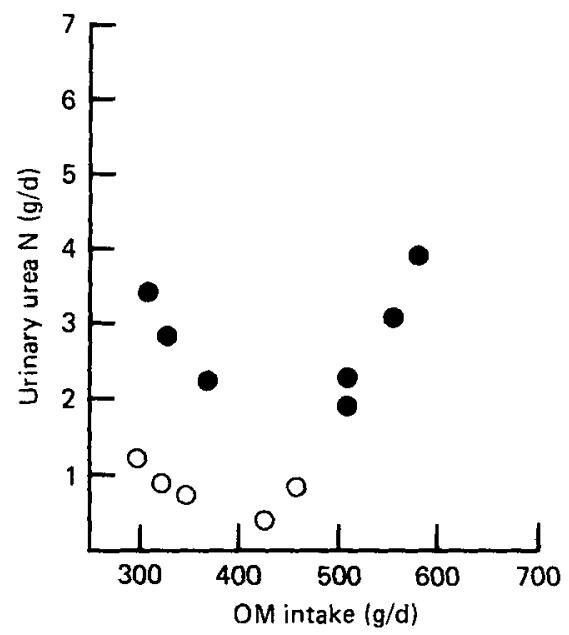

Fig. 3. The excretion rate of urea (g urea nitrogen/d) in the urine of sheep given Agrostis-Festuca (O) and heather $(O)$ diets at various organic matter intakes.

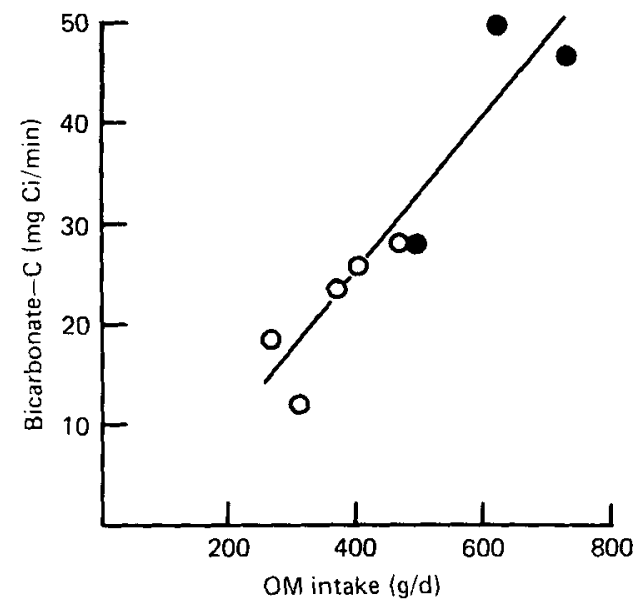

Fig. 4. The relationship between the production rate of rumen bicarbonate $\mathrm{C}(Y, \mathrm{mg} \mathrm{C} / \mathrm{min})$ in sheep given Agrostis-Festuca $(O)$ and heather $(O)$ diets and organic matter intakes $(X, g /$ day). The regression equation was $Y=0.793( \pm 0.0113) X-6.23$.

\section{Expt. 2. Recycling of urea}

Whole-animal urea kinetics. There was no relationship between plasma urea- $N$ concentration [Agrostis-Festuca $2 . \mathrm{I} \pm 0.20 \mathrm{~mm}(n)$ ); heather $1.0 \pm 0.23 \mathrm{~mm}(n$ 4)] or entry rate [Agrostis-Festuca $5.3 \pm 0.65(n$ ) ; heather $2.7 \pm 0.31 \mathrm{~g}$ urea N/d $(n 4)]$ and OM intake. Similarly, there was no relationship between the percentage transfer of plasma urea $\mathrm{C}$ to rumen bicarbonate C [Agrostis-Festuca $0.94 \pm 0.16(n)$; heather $1.15 \pm .025(n 4)]$ and OM intake.

The relationship between rumen bicaronate- $C$ irreversible loss rate and OM intake for the five observations on sheep given Agrostis-Festuca and the three observations on heather are given in Fig. 4. The values for the two diets were combined and an over-all regression is given $(P<0.001)$. 
An estimate of urea $C$ entering the rumen bicarbonate pool was obtained as the product of the rumen bicarbonate $C$ production rate multiplied by the percentage transfer of plasma urea $C$ to rumen bicarbonate $C$. At the $460 \mathrm{~g} \mathrm{OM} / \mathrm{d}$ intake level it was estimated from the regression given in Fig. 4 that 0.28 and $0.33 \mathrm{mg}$ urea-C/min entered the rumen pool in sheep given Agrostis-Festuca and heather diets respectively. This was equivalent to 0.9 and I I g urea $\mathrm{N} / \mathrm{d}$ respectively.

\section{DISCUSSION}

As with other low-quality roughages (Harris \& Phillipson, 1962; Clarke et al. 1966; Hogan \& Weston, 1967; Weston \& Hogan, 1968; Egan, 1974) there was substantially more NAN arriving at the dueodenum of sheep given the Agrostis-Festuca diet than was consumed and the net digestibility of this NAN in the small intestine was within the range $(0.55-0.80)$ reported for forage diets (e.g. Clarke et al. 1966; MacRae et al. 1972; Coelho Da Silva et al. 1972; MacRae \& Ulyatt, I 974; Armstrong \& Hutton, 1975). However when the sheep consumed heather, although there was a substantial net addition of NAN anterior to the duodenum, the net digestibility of this NAN within the small intestine $(0.43)$ was much lower than with the Agrostis-Festuca diet $(0.58)$. This may have been caused by the irreversible complexing of protein with the tannins present in heather, as discussed by Milne (1974). Egan \& Ulyatt (1979) have recently reported that the net digestibility of NAN within the small intestine of sheep given sanfoin (Onobrychis viciifolia), another plant species which contains tannin, was found to be $0.07-0.10$ lower than when either ryegrass or clover diets were fed.

Since urea enters the rumen via saliva (McDonald, 1948; Somers, 1961) and by direct diffusion from the blood (Houpt, 1959; Somers, 196I; Ash \& Dobson, 1963) and since urea is rapidly hydrolysed in the rumen (Pearson \& Smith, 1943) and ammonia $N$ is assimilated by some rumen bacteria (Phillipson et al. 1959, 1962) it has always been assumed that a large proportion of the extra $\mathrm{N}$ arriving at the duodenum is derived from recycled blood urea $\mathrm{N}$ (Clarke et al. I 966), the rumen micro-organisms thus converting non-protein $\mathrm{N}$ into protein for subsequent use by the host animal.

Before discussing the present results it is perhaps necessary to pass some comment on the method used to measure urea recycling in this study. It has been suggested that where transfer quotients are being measured for a dynamic system in which tracer is moving in more than one direction, it is not sufficient to calculate the net flow in any one direction simply as secondary:primary curve area ratio $\times$ irreversible loss from secondary pool. Instead a multiple-pool model approach, employing simultaneous equations to calculate inputs and outputs from the different pools should be adopted (see Nolan et al. 1976). Indeed, such procedures have been commonly employed to calculate transfers of ${ }^{15} \mathrm{~N}$ in models of plasma urea, rumen $\mathrm{NH}_{3}$ and/or caecal $\mathrm{NH}_{3}$ (Nolan et al. 1976; Kennedy \& Milligan, I978), ${ }^{14} \mathrm{C}$ in models of blood-, rumen- and caecal carbon dioxide (MacRae et al. 1978) or threonine-, glucose- and $\mathrm{CO}_{2}-\mathrm{C}$ systems (Egan \& MacRae, 1978) where there is considerable two-way transfer of tracers. However, in the present system, because of the relative pool sizes of the plasma urea and bicarbonate pools, the potential for recycling of urea $C$ to the plasma urea $C$ pool after degradation to rumen bicarbonate $C$ is so small as to be biologically insignificant. Thus, if the SA of rumen bicarbonate is only approximately 0.01 of that of blood urea $\mathrm{C}$ and if this rumen bicarbonate is mixed with approximately twice its own amount of tissue-produced bicarbonate C (MacRae et al. 1978), the maximum of SA of recycling urea $\mathrm{C}$ will be no more than 0.0033 of that in the primary pool.

The results of this experiment do not support the hypothesis that most of the extra NAN is derived from urea $\mathrm{N}$. It was calculated (see Table 2) that of the extra $3.7 \mathrm{~g} \mathrm{NAN}$ of Agrostis-Festuca/d and $3.3 \mathrm{~g}$ NAN of heather/d, only 0.9 and I.I $\mathrm{g} / \mathrm{d}$ respectively could be 
accounted for as urea $N$. Since a preliminary report of this work was presented (MacRae et al. 1977), Norton et al. (1978) have reported similar findings with indigenous pastures from the semi-arid zones of Australia, i.e. only $0.45-0.65 \mathrm{~g}$ urea $\mathrm{N} / \mathrm{d}$ on diets of Flinders (Iseilema sp.) grass, Mitchell (Astrebla sp.) grass or mixed pasture entered the rumen ammonia pool. Kennedy \& Milligan (1977) reported much higher values for the utilization of urea $\mathrm{N}$ recycled into the rumen of animals given pelleted brome grass (Bromus inermis) (3.2 $\mathrm{g}$ urea $\mathrm{N}$ incorporated into microbial protein entering the small intestine).

The reasons for these conflicting observations are not fully understood. Kennedy \& Milligan (1978) suggested that rumen ammonia concentration (7-8 mM for the brome grass) was inversely related to the recycling of urea in their experiments. However, this suggestion is hard to reconcile with the results of indigenous herbage diets of the present study and of the study by Norton et al. (1978), where in both instances the rumen ammonia concentrations were lower than on the brome grass diet $(<2 \mathrm{~mm}$ in the present study; $2,2.5$ and $5 \mathrm{~mm}$ on the three diets fed by Norton et al. 1978 ). Possibly the fact that the brome grass diet had been heat-denatured during processing, which resulted in its $\mathrm{N}$ being rendered relatively unavailable to rumen micro-organisms, yet subsequently available for digestion and absorption in the small intestine, might have some bearing on the differences. It would appear therefore that the magnitude of the urea recycling cannot be related to any one simple measurement such as ammonia concentration. Whether it can be any better related to variables such as the relative rates of $\mathrm{N}$ and energy utilization in the rumen or alternatively to the relative concentrations of plasma urea and rumen ammonia will require further experimentation.

The calculated values of $2 \cdot 8$ (Agrostis-Festuca) and $2 \cdot 2$ (heather) g non-urea endogenous $\mathrm{N}$ arriving at the duodenum (see Table 2 ) are likely to be minimum values. Studies using ${ }^{15} \mathrm{~N}$ tracers (Nolan \& MacRae, 1976; Salter \& Smith, 1977) have shown that a large proportion of the rumen ammonia production is absorbed directly from the rumen and is not converted into microbial protein. Any loss of dietary $\mathrm{N}$ as ammonia would lead to an underestimate of the contribution of endogenous NAN. For example, Nolan \& MacRae ( 1976 ) found that when a high-quality lucerne-cube diet ( $N$ intake $16 \mathrm{~g} / \mathrm{d}$ ) was fed, amounts of NAN arriving at the duodenum were $17 \mathrm{~g} / \mathrm{d}$. This would suggest that most of the addition could be accounted for by recycling of $1.5 \mathrm{~g}$ urea $\mathrm{N}$. It was shown, however, that $0.5-0.6$ of the ammonia production was absorbed directly rather than converted to microbial protein and this then required 3-4 $\mathrm{g}$ endogenous non-urea $\mathrm{N}$ to be added anterior to the duodenum to account for the duodenal NAN flow (see MacRae \& Reeds 1979).

The levels of intake of Agrostis-Festuca and heather used in this experiment provided only half the maintenance energy requirements of these animals. At the lowest intakes catabolism of tissue protein may have caused the elevated urinary urea- $\mathrm{N}$ excretion rates found in Expt I (see Fig. 3). Between 400 and $500 \mathrm{~g} \mathrm{OM} / \mathrm{d}$ the increased DE intakes may have been such that catabolism of tissue protein was less, resulting in reduced urea- $N$ excretion rates. At the higher intakes of Agrostis-Festuca the diet would have been supplying excess $\mathrm{N}$ relative to the energy available in the rumen and thus urinary urea- $\mathrm{N}$ excretion rates would have increased. In the experiments of Milne et al. (1979), when heather was supplemented with urea, urea- $\mathrm{N}$ excretion rose as $\mathrm{N}$ intake increased in a similar manner to the present results for the Agrostis-Festuca diet.

The present experiments would suggest that the Agrostis-Festuca diet has digestive characteristics similar to many low-quality dried roughages. However heather has a low availability of digesta NAN in the small intestine, and because of the high amount of endogenous non-urea $\mathrm{N}$ secreted into the digestive tract anterior to the duodenum this may have a serious consequence on the $\mathrm{N}$ economy of animals ingesting a predominantly heather diet. 


\section{REFERENCES}

Armstrong, D. G. \& Hutton, K. (1975). In Digestion and Metabolism in the Ruminant, p. 432 [I. W. McDonald and A. C. I. Warner, editors]. Armidale, NSW: University of New England Publishing Unit. Armstrong, R. H. \& Eadie, J. (1977). J. agric. Sci. Camb. 88, 683.

Ash, R. W. \& Dobson, A. (1963). J. Physiol. 169, 39.

Binnerts, W. T., van't Klooster, A. Th. \& Frens, A. M. (1968). Vet. Rec. 82, 470.

Clarke, E. M. W., Ellinger, G. M. \& Phillipson, A. T. (1966). Proc. R. Soc. Lond. B 166, 63.

Coccimano, M. R. \& Leng, R. A. (1967). Br. J. Nutr. 21, 353.

Coelho da Silva, J. F., Seeley, R. C., Thomson, D. J., Beever, D. E. \& Armstrong, D. G. (1972). Br. J. Nutr. 28, 43 .

Conway, E. J. (1957). In Micro-diffusion Analysis and Volumetric Error, 4th ed. London: Lockwood.

Egan, A. R. (1974). Aust. J. agric. Res. 25, 613.

Egan, A. R. \& MacRae, J. C. (1978). Proc. Nutr. Soc. 37, I5A.

Egan, A. R. \& Ulyatt, M. J. (1979). J. agric. Sci. Camb. 92,605.

Harris, L. E. \& Phillipson, A. T. (1962). Anim. Prod. 4, 97.

Hecker, J. F. (1974). In Experimental Surgery on Small Ruminants, p. 126. London: Butterworths.

Hogan, J. P. \& Weston, R. H. (1967). Aust. J. agric. Res. r8, 803.

Houpt, T. R. (1959). Am. J. Physiol. 197, I 15.

Kay, R. N. B. \& McKenzie, J. D. (1968). J. Sci. Technol. 14, 15.

Kennedy, P. M. \& Milligan, L. P. (1977). Proc. Nutr. Soc. 36, 53 A.

Kennedy, P. M. \& Milligan, L. P. (1978). Br. J. Nutr. 40, 149.

Leng, R. A. \& Leonard, G. J. (1965). Br. J. Nutr. 19, 469.

McDonald, I. W. (1948). Biochem. J. 42, 58 A.

MacRae, J. C. \& Reeds, P. J. (1979). Proc. 29 Nottingham Easter School [P. J. Buttery \& D. B. Lindsay, editors]. (In the Press.)

MacRae, J. C., Reid, C. S. W., Dellow, D. W. \& Wyburn, R. S. (1973), Res. vet. Sci. 14, 78.

MacRae, J. C. \& Ulyatt, M. J. (1974). J. agric. Sci. Camb. 82, 309.

MacRae, J. C., Ulyatt, M. J., Pearce, P. D. \& Hendtlass, J. (1972). Br. J. Nutr. 27, 39.

MacRae, J. C. \& Wilson, S. (1978). Int. J. appl. Radiat. Isotopes 29, I91.

MacRae, J. C., Wilson, S. \& Milne, J. A. (1978). Proc. Nutr. Soc. 37, 16 A.

MacRae, J. C., Wilson, S., Milne, J. A. \& Spence, A. M. (1977). Proc. Nutr. Soc. 36, 77 A.

Marsh, W. H., Fingerhut, B. \& Miller, H. (1965). Clin. Chem. 11, 624.

Milne, J. A. (1974). J. agric. Sci. Camb. 83, 281.

Milne, J. A., Christie, A. \& Russel, A. J. F. (1979). J. agric. Sci. Camb. 92, 635.

Nolan, J. V. \& Leng, R. A. (1974). Proc. Nutr. Soc. 33, 1 .

Nolan, J. V. \& MacRae, J. C. (I976). Proc. Nutr. Soc. 35, I Io A.

Nolan, J. V., Norton, B. W. \& Leng, R. A. (1976). Br. J. Nutr. 35, 127.

Norton, B. W., Murray, R. M., Entwistle, K. W., Nolan, J. V., Ball, F. M. \& Leng, R. A. (1978). Aust. J. agric. Res. 29, 595.

Pearson, R. M. \& Smith, J. A. B. (1943). Biochem. J. 37, 153.

Phillipson, A. T., Dobson, M. J. \& Blackburn, T. H. (1959). Nature, Lond. 183, 402.

Phillipson, A. T., Dobson, M. J., Blackburn, T. H. \& Wilson, M. (1962). Br. J. Nutr. 16, 151.

Russel, A. J. F., Doney, J. M. \& Gunn, R. G. (1969). J. agric. Sci. Camb. 72, 45 I.

Russel, A. J. F., Gunn, R. G. \& Doney, J. M. (1968). Anim. Prod. Io, 43.

Salter, D. N. \& Smith, R. H. (1977). Proc. Nutr. Soc. 36, 54 A.

Somers, M. (1961). Aust. J. exp. Biol. med. Sci. 39, I 23.

Steel, R. G. D. \& Torrie, J. H. (1960). Principles and Procedures of Statistics. New York: McGraw-Hill.

Tan, N. H., Weston, R. H. \& Hogan, J. P. (1971). Int. J. appl, Radiat. Isotopes 22, 301.

Weston, R. H. \& Hogan, J. P. (1968). Aust. J. agric. Res. 19, 567. 